\title{
Therapeutic Facet Joint Interventions in Chronic Spinal Pain: A Systematic Review of Effectiveness and Complications
}

\author{
Mark V. Boswell, MD, PhD, James D. Colson, MD, and William F. Spillane, MD
}

Background: Facet joint interventions are used frequently for managing chronic spinal pain. Evidence continues to accumulate supporting the clinical effectiveness of these procedures and defining potential complications.

Objective: To evaluate the effectiveness of three types of facet joint interventions (facet joint injections, medial branch blocks and facet joint neurotomy) in managing spinal pain.

Study Design: A systematic review utilizing the criteria established by the Agency for Healthcare Research and Quality (AHRQ) for evaluation of randomized and non-randomized trials and Cochrane Musculoskeletal Review Group for randomized trials.

Methods: Data sources included relevant literature of the English language identified through searches of MEDLINE and EMBASE (January 1966 to November 2004), manual searches of bibliographies of known primary and review articles, and abstracts from scientific meetings within the last 2 years.

Analyses were performed for the different modes of facet joint interventions of cervical, thoracic and lumbar spine, to determine short- and long-term outcome measurements and complications associated with the procedures.

Outcome Measures: The primary outcome measure was pain relief. For facet joint injections and medial branch blocks, short-term pain relief was defined as relief less than 6 weeks, and long-term as 6 weeks or longer. For medial branch radiofrequency neurotomy, short-term relief was defined as pain relief of less than 3 months, and longterm as 3 months or longer. Other outcome measures included functional improvement, improvement of psychological status, and re- turn to work.

Results: For lumbar intraarticular facet joint injections, there was moderate evidence for short-term improvement, and limited evidence for long-term improvement. The evidence was negative for cervical intraarticular facet joint injections.

For cervical and lumbar medial branch blocks with local anesthetics and steroids, the evidence was moderate.

The evidence for pain relief with radiofrequency neurotomy of medial branch nerves was moderate to strong.

Conclusion: The evidence for facet joint interventions ranged from negative to strong.

Keywords: Spinal pain, neck pain, low back pain, facet or zygapophysial joints, intraarticular facet joint injections, medial branch blocks, medial branch radiofrequency neurotomy
The concept that facet (zygapophysial) joints can cause low back pain was proposed by Goldthwait (1) in 1911. Since then, numerous investigators have suggested that facet joints can cause lumbar, thoracic and cervical spine pain (24). Indeed, there is an extensive body of

From Department of Anesthesiology, University Hospitals of Cleveland, Cleveland, $\mathrm{OH}$, Center for Interventional Pain Medicine, University of Michigan, Ann Arbor, MI, and Pain Control Center, Department of Anesthesiology, Wake Forest University Baptist Medical Center, Winston-Salem, NC

Address Correspondence: Mark V. Boswell, MD, PhD, Chief, Pain Medicine Service, 2533 Lakeside, University Hospitals of Cleveland, 11100 Euclid Avenue, Cleveland, Ohio 44106

Disclaimer: Nothing of monetary value was received in the preparation of this manuscript.

Conflict of Interest: None

Acknowledgement:

Manuscript received on 12/14/2004

Revision submitted on 01/06/2005

Accepted for publication on 01/06/2005 evidence supporting the existence of facet joint pain (2-30), although some dispute the validity of the diagnosis (31-34).

In addition to causing localized spinal pain, facet joints may refer pain to adjacent structures. Pain referral patterns of facet joints have been well described (718). Cervical facet joint pain may radiate to the neck, head and shoulders and lumbar facet joint pain may refer to the back, buttocks and proximal lower extremities. Referred pain may assume a pseudoradicular pattern, making the underlying diagnosis difficult to confirm. There is a growing impression that diagnostic blocks are needed to confirm facet joints as a source of the pain in a given patient, because there is little or no evidence that facet joint pain can be diagnosed on the basis of clinical examination or by medical imaging alone (6, 28-30, 35-59).

Cervical, thoracic and lumbar fac- et joints are innervated by the medial branches of the dorsal rami (19-29). Facet joints can be blocked by intraarticular injections or by anesthetizing the medial branches of the dorsal rami, which innervate the target joint.

In accordance with criteria established by the International Association for the Study of Pain (59), zygapophysial (facet) joints have been shown to be the source of chronic pain in $15 \%$ to $45 \%$ of patients with chronic low back pain (37, $38,46,47,53,54), 54 \%$ to $60 \%$ of the patients with chronic neck pain (54-57) and $42 \%$ to $48 \%$ of the patients with thoracic pain $(54,58)$. These prevalence numbers are derived from analysis of placebo-controlled blocks or comparative local anesthetic blocks. Specificity, sensitivity, and reliability of comparative local anesthetic blocks against placebo, as well as a lack of reliability of single blocks 
have been shown $(2-4,6,38,46,47,51,52$, $54,57,58)$.

Facet joint pain may be managed by intraarticular injections, medial branch blocks and neurolysis of medial branch nerves. However, conflicting results have been reported for the value of intraarticular injections of facet joints, medial branch blocks, and radiofrequency neurolysis of medial branches in several systematic and narrative reviews (60$65)$. Further, none of the systematic reviews evaluated all three interventions, independently or in combination.

This review was undertaken to assess systematically, the effectiveness of intraarticular facet joint blocks, medial branch blocks and medial branch radiofrequency denervation in the treatment of chronic spinal pain of facet joint origin.

\section{MethOdS}

\section{Literature Search}

The literature search included MEDLINE and EMBASE (Jan 1966 - Nov 2004), Cochrane database, systematic reviews, narrative reviews, cross-references to the reviews and various published trials, and peer reviewed abstracts from scientific meetings during the past two years, published in the English language. The

Table 1. AHRQ's key domains and elements for systems to rate the quality of randomized controlled trials

\begin{tabular}{|c|c|}
\hline Domain ${ }^{\#}$ & Elements $^{*}$ \\
\hline Study Question & - Clearly focused and appropriate question \\
\hline \multirow[t]{3}{*}{ Study Population } & - Description of study population \\
\hline & - Specific inclusion and exclusion criteria \\
\hline & - Sample size justification \\
\hline \multirow[t]{3}{*}{ Randomization } & - Adequate approach to sequence generation \\
\hline & - Adequate concealment method used \\
\hline & - Similarity of groups at baseline \\
\hline Blinding & $\begin{array}{l}\text { - Double-blinding (e.g., of investigators, caregivers, subjects, assessors, and } \\
\text { other key study personnel as appropriate) to treatment allocation }\end{array}$ \\
\hline \multirow[t]{3}{*}{ Interventions } & $\begin{array}{l}\text { - Intervention(s) clearly detailed for all study groups (e.g., dose, route, timing } \\
\text { for drugs, and details sufficient for assessment and reproducibility for other } \\
\text { types of interventions) }\end{array}$ \\
\hline & - Compliance with intervention \\
\hline & - Equal treatment of groups except for intervention \\
\hline \multirow[t]{2}{*}{ Outcomes } & - Primary and secondary outcome measures specified \\
\hline & - Assessment method standard, valid, and reliable \\
\hline \multirow[t]{4}{*}{ Statistical Analysis } & $\begin{array}{l}\text { - Appropriate analytic techniques that address study withdrawals, loss to } \\
\text { follow-up, missing data, and intention to treat }\end{array}$ \\
\hline & - Power calculation \\
\hline & - Assessment of confounding \\
\hline & - Assessment of heterogeneity, if applicable \\
\hline \multirow[t]{2}{*}{ Results } & - Measure of effect for outcomes and appropriate measure of precision \\
\hline & $\begin{array}{l}\text { - Proportion of eligible subjects recruited into study and followed up at each } \\
\text { assessment }\end{array}$ \\
\hline Discussion & $\begin{array}{l}\text { - Conclusions supported by results with possible biases and limitations taken } \\
\text { into consideration }\end{array}$ \\
\hline $\begin{array}{l}\text { Funding or } \\
\text { Sponsorship }\end{array}$ & - Type and sources of support for study \\
\hline
\end{tabular}

"Key domains are in italics

*Elements appearing in italics are those with an empirical basis. Elements appearing in bold are those considered essential to give a system a Yes rating for the domain. For purposes of this systematic review, the bold elements were considered, and to be included studies needed to have at least 5 of the 10 essential elements. Adapted from ref. 66 search strategy consisted of diagnostic interventional techniques, facet (zygapophysial joint) injections with local anesthetics and steroids, medial branch facet nerve blocks with local anesthetics and steroids, and medial branch (facet nerve) radiofrequency neurotomy. The emphasis of the analysis was on chronic spinal pain of facet joint origin.

\section{Selection Criteria And Data Extraction}

This review focused on randomized and observational studies, and reports of complications. The population of interest was patients suffering with chronic spinal pain for at least 3 months who underwent facet joint injections and medial branch blocks and 6 months for radiofrequency neurotomy. To be included in this review, ideally, all studies should have documented the existence of spinal pain of facet origin using controlled diagnostic facet joint or nerve blocks. Due to the scarcity of such studies, some studies with single blocks were also considered.

Three types of facet interventions were included in this review: intraarticular facet joint injections, medial branch blocks, and medial branch radiofrequency neurotomy. All studies providing appropriate management with outcome evaluations of at least 3 months and statistical analysis were reviewed. The primary outcome measure was pain relief at various time points. The secondary outcome measures were functional or psychological improvement, return to work, and complications.

For evaluating the quality of individual articles, we used the criteria from the Agency for Healthcare Research and Quality (AHRQ) (66). Important domains and elements for randomized and observational trials, are shown in Tables 1 and 2. For inclusion, studies must have met at least $50 \%$ of the key domains and elements. Criteria described by the Cochrane Review Group for Musculoskeletal Disorders (67) were also used for evaluation of randomized trials, as shown in Appendix A.

Each study was evaluated for inclusion criteria, the study population, outcomes data, and statistical analysis. Inclusion criteria are shown in Appendix B, and a study should have answered questions in a positive manner (at least partially) in all categories. 
Table 2. AHRQ's key domains and elements for systems to rate quality of observational studies

\begin{tabular}{|c|c|}
\hline Domain $^{\#}$ & Elements \\
\hline Study Question & - Clearly focused and appropriate question \\
\hline \multirow[t]{2}{*}{ Study Population } & - Description of study populations \\
\hline & - Sample size justification \\
\hline \multirow{11}{*}{$\begin{array}{l}\text { Comparability of } \\
\text { Subjectst }\end{array}$} & For all observational studies: \\
\hline & - Specific inclusion/exclusion criteria for all groups \\
\hline & - Criteria applied equally to all groups \\
\hline & $\begin{array}{l}\text { - Comparability of groups at baseline with regard to disease status and } \\
\text { prognostic factors }\end{array}$ \\
\hline & $\begin{array}{l}\text { - Study groups comparable to non-participants with regard to confounding } \\
\text { factors }\end{array}$ \\
\hline & - Use of concurrent controls \\
\hline & - Comparability of follow-up among groups at each assessment \\
\hline & Additional criteria for case-control studies: \\
\hline & - Explicit case definition \\
\hline & - Case ascertainment not influenced by exposure status \\
\hline & $\begin{array}{l}\text { - Controls similar to cases except without condition of interest and with } \\
\text { equal opportunity for exposure }\end{array}$ \\
\hline \multirow[t]{3}{*}{ Exposure or Intervention } & - Clear definition of exposure \\
\hline & - Measurement method standard, valid and reliable \\
\hline & - Exposure measured equally in all study groups \\
\hline \multirow[t]{4}{*}{ Outcome Measurement } & - Primary/secondary outcomes clearly defined \\
\hline & - Outcomes assessed blind to exposure or intervention status \\
\hline & - Method of outcome assessment standard, valid and reliable \\
\hline & - Length of follow-up adequate for question \\
\hline \multirow[t]{6}{*}{ Statistical Analysis } & - Statistical tests appropriate \\
\hline & - Multiple comparisons taken into consideration \\
\hline & - Modeling and multivariate techniques appropriate \\
\hline & - Power calculation provided \\
\hline & - Assessment of confounding factors \\
\hline & - Dose-response assessment, if appropriate \\
\hline \multirow[t]{2}{*}{ Results } & - Measure of effect for outcomes and appropriate measure of precision \\
\hline & - Adequacy of follow-up for each study group \\
\hline Discussion & $\begin{array}{l}\text { - Conclusions supported by results with possible biases and limitations } \\
\text { taken into consideration }\end{array}$ \\
\hline Funding or Sponsorship & - Type and sources of support for study \\
\hline
\end{tabular}

"Key domains are in italics

${ }^{*}$ Elements appearing in italics are those with an empirical basis. Elements appearing in bold are those considered essential to give a system a Yes rating for the domain. For purposes of this systematic review, the bold elements were considered, and to be included studies needed to have at least 5 of the 8 essential elements.

$\dagger$ Domain for which a Yes rating required that a majority of elements be considered. Adapted from ref. 66

\section{Analysis of Evidence}

Qualitative analysis was conducted, using five levels of evidence for effective- ness as illustrated in Table 3. Pain relief

was evaluated on both a short-term (less than 6 weeks) and long-term (6 weeks or longer) basis for intraarticular injections and medial branch blocks, whereas less than 3 months was considered as short-term and 3 months or longer was considered long-term for radiofrequency neurotomy. For randomized trials, a study was judged to be positive if the facet joint intervention was more effective than the reference treatment. For observational studies, results were considered positive if the treatment was effective by defined criteria (e.g., $>50 \%$ pain relief). All other conclusions were considered negative. If, in the opinion of the reviewers, there were inconsistencies in the conclusions, disagreements were resolved by discussion and consensus.

\section{RESULTS}

\section{Intraarticular Facet Joint Blocks}

Our search strategy identified a total of 235 articles. There were 11 relevant articles that were deemed eligible for further consideration of inclusion criteria.

\section{Methodological Quality}

Four randomized studies of intraarticular lumbar steroid facet joint injections (68-71) and one randomized study of the cervical spine (72) were identified, which compared results to those of similar groups not receiving intraarticular steroids. Of these, Carette et al (68) and Barnsley et al (72) met the inclusion criteria and methodological quality criteria (Table 4). Other randomized trials by Lilius et al (69), Marks et al (70), and Nash (71) did not meet inclusion criteria and were excluded. Marks et al (70) and Nash (71) compared the effects of intraarticular injections with medial branch blocks. Even though the number of patients included was of clinical significance with 86 and 67, respectively, patient selection failed to include controlled diagnostic blocks, there was not a blinded evaluation by an independent observer, and the authors utilized poor assessment tools. Lilius et al (69) included patients with neurological deficits, failed to confirm diagnosis, and used excessive volumes ( $3 \mathrm{~mL}$ to 8 $\mathrm{mL}$ ) of active agents.

Two of the randomized studies, one by Carette et al (68) involving lumbar facet joint injections and the second one by Barnsley et al (72) involving cervical facet joint injections, are considered high quality and have been repeatedly quoted in the literature. Details of randomized tri- 
Table 3. Designation of levels of evidence

\begin{tabular}{|l|l|}
\hline Level I & $\begin{array}{l}\text { Conclusive: Research-based evidence with multiple relevant and high-quality scientific } \\
\text { studies or consistent reviews of meta-analyses }\end{array}$ \\
\hline Level II & $\begin{array}{l}\text { Strong: Research-based evidence from at least one properly designed randomized, controlled } \\
\text { trial; or research-based evidence from multiple properly designed studies of smaller size; or } \\
\text { multiple low quality trials. }\end{array}$ \\
\hline Level III & $\begin{array}{l}\text { Moderate: a) Evidence obtained from well-designed pseudorandomized controlled trials } \\
\text { (alternate allocation or some other method); b) evidence obtained from comparative studies } \\
\text { with concurrent controls and allocation not randomized (cohort studies, case-controlled } \\
\text { studies, or interrupted time series with a control group); c) evidence obtained from } \\
\text { comparative studies with historical control, two or more single-arm studies, or interrupted } \\
\text { time series without a parallel control group. }\end{array}$ \\
\hline Level IV & $\begin{array}{l}\text { Limited: Evidence from well-designed nonexperimental studies from more than one center or } \\
\text { research group; or conflicting evidence with inconsistent findings in multiple trials }\end{array}$ \\
\hline Level V & $\begin{array}{l}\text { Indeterminate: Opinions of respected authorities, based on clinical evidence, descriptive } \\
\text { studies, or reports of expert committees. }\end{array}$ \\
\hline
\end{tabular}

als included in the evidence synthesis and methodological quality for intraarticular injections are shown in Table 4. Even though methodological criteria for both the above studies was considered optimal, Carette et al (68) failed to exclude placebo responders, which may account for the relatively high incidence of pa- tients in their study with presumed facet joint pain. They showed a prevalence of lumbar facet joint pain of $58 \%$ in patients with spine pain, based on inclusion criteria in Phase I of the study. False-positive rates have been evaluated by multiple investigators with a calculated prevalence of facet pain of $17 \%$ to $47 \%$ for the lumbar spine $(16,46,47,53,54)$. Consequently, failure to exclude placebo responders diluted the findings of true responses, making detection of differences between the study and control groups difficult. Further, even though results were judged to be positive at 6 months in the methylprednisolone group, they performed various types of analyses and finally concluded that there was no significant difference between groups.

Barnsley et al (72) performed a well-conducted study, but faced criticism. They included a total of 41 patients whose origin of neck pain was posttraumatic, following whiplash. Consequently, results may not be extrapolated to treatment of patients with cervical facet joint pain from nontraumatic causes, because responses to intraarticular steroid injections is not known for cervical facet joint pain of spontaneous origin.

Among the observational reports, numerous studies were evaluated for inclusion. Among these, five studies (73-

Table 4. Characteristics of published randomized trials of intraarticular facet joint injections

\begin{tabular}{|c|c|c|c|c|c|}
\hline Study/Methods & Participants & Interventions & Outcome(s) & Result(s) & $\begin{array}{l}\text { Conclusion }(s) \\
\text { Short-term relief }<6 \text { weeks } \\
\text { Long-term relief } \geq 6 \text { weeks }\end{array}$ \\
\hline \multicolumn{6}{|l|}{ Lumbar Spine } \\
\hline $\begin{array}{l}\text { Carrette et al (68) } \\
\text { Lumbar facet joint } \\
\text { injections } \\
\text { Randomized, double- } \\
\text { blind, placebo- } \\
\text { controlled trial } \\
\text { AHRQ Score } \\
10 / 10 \\
\text { Cochrane Score } \\
10 / 10\end{array}$ & $\begin{array}{l}190 \text { patients entered } \\
\text { Phase I of the } \\
\text { study. Of these, } 110 \\
(58 \%) \text { reported a } \\
\text { reduction of } 50 \% \text { or } \\
\text { more in their pain } \\
\text { after the injections } \\
\text { of lidocaine. Nine } \\
\text { patients were not } \\
\text { included in the } \\
\text { study. Thus, } 101 \\
\text { patients entered the } \\
\text { randomized trial } \\
\text { (Phase II), } 51 \text { in the } \\
\text { methylprednisolone } \\
\text { group, and } 50 \text { in the } \\
\text { placebo group. }\end{array}$ & $\begin{array}{l}\text { The patients received } \\
\text { injections of either } \\
20 \mathrm{mg}(1 \mathrm{~mL}) \text { of } \\
\text { methylprednisolone } \\
\text { acetate mixed with } \\
1 \mathrm{~mL} \text { of isotonic } \\
\text { saline or } 2 \mathrm{~mL} \text { of } \\
\text { isotonic saline in each } \\
\text { of the facet joints. } \\
\text { All the injections } \\
\text { were preceded by } \\
\text { arthrography and } \\
\text { were performed under } \\
\text { fluoroscopic guidance. }\end{array}$ & $\begin{array}{l}95 \text { patients } \\
\text { of } 101 \text { were } \\
\text { followed for } \\
6 \text { months } \\
\text { and their } \\
\text { condition } \\
\text { assessed with } \\
\text { scales of pain } \\
\text { severity, back } \\
\text { mobility, and } \\
\text { limitation of } \\
\text { function. }\end{array}$ & $\begin{array}{l}42 \% \text { of the patients who } \\
\text { received methylprednisolone } \\
\text { and } 33 \% \text { of those who received } \\
\text { placebo reported marked or very } \\
\text { marked improvement with no } \\
\text { significant difference among the } \\
\text { groups at } 3 \text { months and after } \\
3 \text { months with no significant } \\
\text { difference at } 1 \text { month and } 3 \\
\text { months. } \\
\text { The proportion of patients } \\
\text { treated with methylprednisolone } \\
\text { who reported marked or very } \\
\text { marked improvement } 6 \text { months } \\
\text { after the injections increased } \\
\text { to } 46 \% \text {, whereas it decreased } \\
\text { to } 15 \% \text { for the patients who } \\
\text { received placebo with a } \\
\text { statistically significant difference } \\
\text { ( } p=0.002\end{array}$ & $\begin{array}{l}\text { Negative short-term } \\
\text { and long-term }\end{array}$ \\
\hline \multicolumn{6}{|l|}{ Cervical Spine } \\
\hline $\begin{array}{l}\text { Barnsley et al ( } 72) \\
\text { Cervical facet joint } \\
\text { injections } \\
\text { Randomized, } \\
\text { double-blind, trial of } \\
\text { intraarticular } \\
\text { AHRQ Score } \\
10 / 10 \\
\text { Cochrane Score } \\
9 / 10\end{array}$ & $\begin{array}{l}41 \text { patients with } \\
\text { cervical pain after } \\
\text { whiplash and } \\
\text { with relief of pain } \\
\text { after controlled } \\
\text { diagnostic blocks } \\
\text { randomized to } \\
\text { intraarticular } \\
\text { steroid or local } \\
\text { anesthetic } \\
\text { cervical facet joint } \\
\text { injections. }\end{array}$ & $\begin{array}{l}\text { Patients randomized } \\
\text { to intraarticular } \\
\text { injection of } 5.7 \mathrm{mg} \\
\text { betamethasone or } \\
1 \mathrm{ml} \text { intraarticular } \\
\text { bupivacaine. }\end{array}$ & $\begin{array}{l}\text { Return } \\
\text { of pain to } \\
50 \% \text { of } \\
\text { preinjection } \\
\text { pain level. }\end{array}$ & $\begin{array}{l}\text { No significant difference in } \\
\text { duration of pain relief. Median } \\
\text { duration of time to return of } \\
\text { pain to } 50 \% \text { was } 3 \text { days in the } \\
\text { steroid group and } 3.5 \text { days in the } \\
\text { local anesthetic group. }\end{array}$ & $\begin{array}{l}\text { Negative short-term } \\
\text { and long-term }\end{array}$ \\
\hline
\end{tabular}


77) met the inclusion criteria. Among the prospective trials included in the evidence synthesis, 3 (73-75) of the 5 studies (73-77) were prospective and 2 were retrospective $(76,77)$. Among these, pain relief was the only outcome measure evaluated in all the studies except in one study, where return to work also was evaluated (76). Characteristics and results of observational studies of intraarticular facet joint injections are illustrated in Table 5 along with methodological scores.

\section{Effectiveness}

Carette et al (68) ultimately concluded that the results of their study were negative at 6 months, although patients who received intraarticular methylprednisolone were considerably improved compared to the control group. Notwithstanding their suggestion that concurrent treatments may have influenced the outcomes, for purposes of this systematic review, in terms of pain relief following intraarticular facet joint injections, the outcome is considered to have been pos- itive for lumbar facet pain at 6 months. The second study, by Barnsley et al (72), obtained negative results with cervical intraarticular injections of steroids and local anesthetic.

Among the non-randomized trials, 3 prospective evaluations $(73-75)$ and 2 retrospective evaluations $(76,77)$ met inclusion criteria. Among the prospective trials included in the evidence synthesis, Lynch and Taylor (75) reported initial pain relief in 31 of 35 patients receiving intraarticular steroids, whereas 8 of the 15 patients receiving extraarticular steroids reported pain relief. Long-term relief was reported in $62 \%$ at 3 months and $56 \%$ at 6 months. Destouet et al (74) reported significant pain relief for 1 to 3 months in $54 \%$ of the patients and for 3 to 6 months in $38 \%$ of the patients. Murtagh (73) reported longterm relief of longer than 3 months in $54 \%$ of patients, although a large fraction of the patients included had nonspecific back pain or radicular symptom. Among the retrospective evaluations, Lippitt (76) reported greater than $50 \%$ relief initially in $42 \%$ of patients, which declined to $14 \%$ at 6 months and $8 \%$ at 12 months. Lau et al (77) reported initial relief in $56 \%$ of patients, which declined to $44 \%$ at 3 months, and $35 \%$ at 6 to 12 months.

\section{Level of Evidence}

Based on the present review, only the randomized trial of lumbar spine pain by Carette et al (68) may be considered to be positive (albeit controversial), however, at 6 months, improvement remained below $50 \%$. In contrast, the second randomized trial of cervical spine pain following whiplash injury by Barnsley et al (72), was negative. Among the non-randomized trials, short-term positive results were noted in 4 of the 5 studies with long-term positive results in, 3 of the 5 studies.

Overall, the evidence was Level III, or moderate for short-term improvement and limited for long-term relief with intraarticular lumbar facet joint injections. The evidence for cervical facet joint pain was negative.

Table 5. Characteristics and results of observational studies of lumbar facet joint injections

\begin{tabular}{|c|c|c|c|c|c|}
\hline Study/Methods & Participants & Intervention(s) & Outcome(s) & Result(s) & $\begin{array}{l}\text { Conclusion }(\mathrm{s}) \\
\text { Short-term relief }<6 \text { weeks } \\
\text { Long-term relief } \geq 6 \text { weeks }\end{array}$ \\
\hline $\begin{array}{l}\text { Murtagh (73) } \\
\text { Prospective study } \\
\text { AHRQ Score -6/8 }\end{array}$ & $\begin{array}{l}100 \text { patients with low } \\
\text { back pain with pain } \\
\text { relief after lumbar } \\
\text { intraarticular facet } \\
\text { joint injections using } \\
\text { fluoroscopy or CT. }\end{array}$ & $\begin{array}{l}\text { Patients with immediate } \\
\text { relief of pain after local } \\
\text { anesthetic injections re- } \\
\text { ceived repeat intraarticular } \\
\text { injection of } 6 \text { mg beta- } \\
\text { methasone. }\end{array}$ & $\begin{array}{l}\text { Follow-up in } \\
\text { all patients. } \\
\text { Subjective relief } \\
\text { as determined } \\
\text { by patient } \\
\text { response. }\end{array}$ & $\begin{array}{l}54 \% \text { of patients had } \\
\text { more than } 3 \text { months } \\
\text { of pain relief. }\end{array}$ & $\begin{array}{l}\text { Positive short-term } \\
\text { and long-term }\end{array}$ \\
\hline $\begin{array}{l}\text { Destouet et al (74) } \\
\text { Prospective study } \\
\text { AHRQ Score -6/8 }\end{array}$ & $\begin{array}{l}54 \text { patients studied; } 13 \\
\text { had previous lumbar } \\
\text { surgery. Patients } \\
\text { received intraarticular } \\
\text { facet injections. }\end{array}$ & $\begin{array}{l}\text { Patients with immedi- } \\
\text { ate relief of pain with } \\
\text { fluoroscopically guided } \\
\text { intraarticular local anes- } \\
\text { thetic injections received } 1 \\
\text { ml } 0.25 \% \text { bupivacaine and } \\
40 \text { mg depot methylpred- } \\
\text { nisolone for treatment. }\end{array}$ & Pain relief. & $\begin{array}{l}54 \% \text { of patients had } \\
\text { initial relief; whereas } \\
38 \% \text { had continued } \\
\text { pain relief for } 3 \\
\text { months or longer. }\end{array}$ & $\begin{array}{l}\text { Positive short-term and } \\
\text { negative long-term }\end{array}$ \\
\hline $\begin{array}{l}\text { Lynch and Taylor } \\
(75) \\
\text { Prospective study } \\
\text { AHRQ Score 6/8 }\end{array}$ & $\begin{array}{l}35 \text { patients in } \\
\text { intraarticular and } \\
15 \text { in extraarticular } \\
\text { group, with presumed } \\
\text { lumbar facet pain were } \\
\text { studied. }\end{array}$ & $\begin{array}{l}\text { Intraarticular or } \\
\text { extraarticular } \\
\text { injections with } 60 \mathrm{mg} \\
\text { methylprednisolone. }\end{array}$ & Pain relief. & $\begin{array}{l}89 \% \text { of patients had } \\
\text { pain relief initially } \\
\text { in the intraarticular } \\
\text { group; intraarticular } \\
\text { injections were better } \\
\text { than extraarticular. }\end{array}$ & $\begin{array}{l}\text { Positive short-term and } \\
\text { long-term }\end{array}$ \\
\hline $\begin{array}{l}\text { Lippitt (76) } \\
\text { Retrospective review } \\
\text { AHRQ Score }-5 / 8\end{array}$ & $\begin{array}{l}99 \text { patients with } \\
\text { clinical diagnosis } \\
\text { of lumbar facet } \\
\text { pain received facet } \\
\text { joint injections with } \\
\text { fluoroscopy. }\end{array}$ & $\begin{array}{l}\text { Intraarticular injection of } 1 \\
\mathrm{ml} 1 \% \text { lidocaine and } 80 \mathrm{mg} \\
\text { depot methylprednisolone. }\end{array}$ & $\begin{array}{l}\text { Pain relief, } \\
\text { return to work. }\end{array}$ & $\begin{array}{l}42 \% \text { of patients had } \\
\text { initial relief which } \\
\text { declined to } 14 \% \text { at } 6 \\
\text { months. }\end{array}$ & $\begin{array}{l}\text { Negative short-term and } \\
\text { long-term }\end{array}$ \\
\hline $\begin{array}{l}\text { Lau et al (77) } \\
\text { Retrospective study } \\
\text { AHRQ Score -6/8 }\end{array}$ & $\begin{array}{l}34 \text { consecutive patients } \\
\text { with clinical diagnosis } \\
\text { of lumbar facet pain } \\
\text { received facet joint } \\
\text { injections with fluo- } \\
\text { roscopy. }\end{array}$ & $\begin{array}{l}\text { Intraarticular injection } \\
\text { of bupivacaine and depot } \\
\text { methylprednisolone. }\end{array}$ & Pain relief. & $\begin{array}{l}56 \% \text { of patients } \\
\text { reported immediate } \\
\text { pain relief, which } \\
\text { declined to } 44 \% \text { at } 3 \\
\text { months and } 35 \% \text { at } 6 \\
\text { to } 12 \text { months. }\end{array}$ & $\begin{array}{l}\text { Positive short-term and } \\
\text { negative long-term }\end{array}$ \\
\hline
\end{tabular}




\section{Medial Branch (Facet Joint Nerve)} Blocks

Our search strategy identified a total of 162 references. There were 6 relevant articles that were deemed eligible for consideration of inclusion criteria.

\section{Methodological Quality}

The therapeutic role of medial branch blocks was evaluated in 4 randomized clinical trials $(70,71,78,79)$ and two non-randomized clinical trials $(80,81)$.

Of the 4 randomized clinical trials $(70,71,78,79)$, only one study by Manchikanti et al (78) met inclusion criteria. Marks et al (70) and Nash (71) compared the effectiveness of intraarticular injections with medial branch blocks. They failed to appropriately diagnose facet joint pain by controlled local anesthetic blocks, and the studies lacked longterm follow-up and outcomes. Further they did not perform the studies to evaluate potential therapeutic benefit. Thus, both studies failed to meet inclusion criteria. The study by Manchikanti et al (81) was excluded, as the study purpose was to evaluate the stability of lumbar facet joint pain diagnosed by controlled, comparative local anesthetic blocks, rather than therapy itself. Consequently, because no other outcome parameters were measured, the study was excluded. The report by Manchikanti et al (79) was also exclud- ed, as it evaluated the therapeutic potential of Sarapin in neural blockade, rather than pain relief on a long-term basis. On the other hand, the randomized controlled trial by Manchikanti et al (78) met inclusion criteria, and was included in the evidence synthesis for lumbar facet pain; the characteristics of this study are shown in Table 6, along with methodological quality criteria.

Among the observational studies, the only study meeting inclusion criteria for evidence synthesis was by Manchikanti et al (80), which evaluated the effectiveness of cervical medial branch blocks in the management of chronic neck pain (Table 6).

\section{Effectiveness}

Only 2 studies, one randomized evaluation (78) and one observational study (79) met methodological criteria and were included in evidence synthesis. The randomized trial (78) evaluated the effectiveness of medial branch blocks in lumbar facet joint pain and the observational study (79) evaluated cervical medial branch blocks for managing chronic neck pain. Both studies showed significant pain relief and improvement in other outcome parameters.

\section{Level of Evidence}

According to the levels of evidence described in Table 3, evidence was mod- erate or level III for short-term and longterm relief with lumbar and cervical medial branch blocks in managing chronic low back or neck pain.

\section{Medial Branch Radiofrequency Neurotomy}

Our search strategy yielded a total of 124 reports. Following detailed review, 17 relevant articles were identified to for subsequent evaluation.

\section{Methodological Quality}

For the current systematic review, four randomized trials evaluating the efficacy of medial branch facet radiofrequency neurotomy were identified, one with cervical medial branch neurotomy (82) and three with lumbar medial branch neurotomy (83-85). Among the randomized trials, only 2 met inclusion criteria. The study by Lord et al (82) evaluated the effectiveness of percutaneous radiofrequency neurotomy from cervical zygapophysial joint pain and the study by van Kleef et al (83) evaluated the effectiveness of radiofrequency lumbar facet denervation for chronic low back pain. The methodological scoring for both of the studies is illustrated in Table 7, along with study descriptions.

Other randomized trials were excluded as they failed to meet inclusion or methodological criteria. The study by

Table 6. Characteristics of published reports of cervical and lumbar medial branch blocks

\begin{tabular}{|c|c|c|c|c|c|}
\hline Study/Methods & Participants & Intervention(s) & Outcome(s) & Result(s) & Conclusion(s) \\
\hline Lumbar Spine & & & & \multicolumn{2}{|c|}{$\begin{array}{l}\text { Short-term relief }<3 \text { months } \\
\text { Long-term relief } \geq 3 \text { months }\end{array}$} \\
\hline $\begin{array}{l}\text { Manchikanti et al, (78) } \\
\text { Lumbar medial branch } \\
\text { blocks } \\
\text { Randomized, } \\
\text { controlled trial } \\
\text { AHRQ Score - } 8 / 10 \\
\text { Cochrane Score - } 6 / 10\end{array}$ & $\begin{array}{l}200 \text { patients with } \\
\text { low back pain } \\
\text { were evaluated. } \\
73 \text { patients were } \\
\text { enrolled in study } \\
\text { after confirmation } \\
\text { of facet pain } \\
\text { by controlled } \\
\text { diagnostic facet } \\
\text { nerve blocks. }\end{array}$ & $\begin{array}{l}\text { Medial branch } \\
\text { blocks with } \\
\text { fluoroscopy. } \\
\text { Patients randomized } \\
\text { into } 2 \text { groups: } \\
\text { local anesthetic, } \\
\text { bupivacaine, with or } \\
\text { without Sarapin }{ }^{\circledR} \text {. } \\
\text { Patients had repeat } \\
\text { procedures as } \\
\text { clinically indicated. }\end{array}$ & $\begin{array}{l}\text { Outcomes were evaluated } \\
\text { over a period of } 2 \frac{1}{2} \text { years. } \\
\text { Measurements were } \\
\text { performed at } 1 \text { month, } \\
3 \text { months, } 6 \text { months, } 12 \\
\text { months, } 18 \text { months, } 24 \\
\text { months, and } 32 \text { months. } \\
\text { Outcomes included pain } \\
\text { relief, physical health, } \\
\text { psychological status, narcotic } \\
\text { intake, and employment } \\
\text { status. }\end{array}$ & $\begin{array}{l}\text { Cumulative significant } \\
\text { relief with } 1 \text { to } 3 \text { injections } \\
\text { up to } 2.5 \text { years. Overall, } \\
\text { significant relief for a mean } \\
\text { of } 6.5 \text { months. } \\
\text { There was significant } \\
\text { improvement noted in } \\
\text { overall health status with } \\
\text { improvement in pain relief, } \\
\text { psychological status, and } \\
\text { return to work status. }\end{array}$ & $\begin{array}{l}\text { Positive short- } \\
\text { term and long } \\
\text { term }\end{array}$ \\
\hline \multicolumn{6}{|l|}{ Cervical Spine } \\
\hline $\begin{array}{l}\text { Manchikanti et al } \\
(80) \\
\text { Cervical medial branch } \\
\text { blocks } \\
\text { Prospective } \\
\text { AHRQ Score }-8 / 8\end{array}$ & $\begin{array}{l}100 \text { consecutive } \\
\text { patients with } \\
\text { cervical facet } \\
\text { pain diagnosed } \\
\text { by comparative, } \\
\text { controlled local } \\
\text { anesthetic blocks. }\end{array}$ & $\begin{array}{l}\text { Medial branch blocks } \\
\text { with fluoroscopy } \\
\text { with bupivacaine } \\
\text { with or without } \\
\text { methylprednisolone. } \\
\text { Patients had repeat } \\
\text { blocks as clinically } \\
\text { indicated. }\end{array}$ & $\begin{array}{l}\text { Pain relief } \\
\text { Oswestry Disability Index } \\
\text { Psychological status } \\
\text { Work status } \\
\text { Timings: } 3 \text { months, } 6 \text { months, } \\
\text { and } 12 \text { months }\end{array}$ & $\begin{array}{l}\text { Significant pain relief at } 3,6 \\
\text { and } 12 \text { months, compared } \\
\text { to baseline measurements. } \\
\text { There was also significant } \\
\text { improvement in disability } \\
\text { status, psychological status, } \\
\text { and return to work. }\end{array}$ & $\begin{array}{l}\text { Positive short- } \\
\text { term and long } \\
\text { term }\end{array}$ \\
\hline
\end{tabular}


Table 7. Characteristics of published randomized trials of medial branch neurotomy

\begin{tabular}{|c|c|c|c|c|c|}
\hline Study/Methods & Participants & Intervention(s) & Outcome(s) & Result(s) & $\begin{array}{l}\text { Conclusion }(\mathbf{s}) \\
\text { Short-term relief }<3 \text { months } \\
\text { Long-term relief } \geq 3 \text { months }\end{array}$ \\
\hline \multicolumn{6}{|l|}{ Cervical Spine } \\
\hline $\begin{array}{l}\text { Lord et al (82) } \\
\text { Cervical zygapophysial } \\
\text { joint nerve radiofrequency } \\
\text { Randomized, placebo- } \\
\text { controlled, double-blind } \\
\text { trial } \\
\text { AHRQ Score - } 9 / 10 \\
\text { Cochrane Score - } 9 / 10\end{array}$ & $\begin{array}{l}24 \text { patients with neck } \\
\text { pain }>3 \text { months' } \\
\text { duration in cervical } \\
\text { spine, confirmed by } \\
\text { controlled blocks } \\
\text { Control }=12 \\
\text { Treatment }=12\end{array}$ & $\begin{array}{l}\text { RF group lesion } 90 \\
\text { sec lesion at } 80^{\circ} \mathrm{C} \\
\text { of medial branch; } \\
\text { Control group } \\
\text { received sham } \\
\text { treatment with } \\
\text { electrode insertion. }\end{array}$ & $\begin{array}{l}3,6 \text { and } 12 \text { month } \\
\text { follow-up; } \\
0 \text { to } 5 \text { of } 100 \text { on } \\
\text { VAS scale; Word } \\
\text { count } 3 \text { or less } \\
\text { on McGill Pain } \\
\text { Questionnaire }\end{array}$ & $\begin{array}{l}\text { Median time to return } \\
\text { of pain in treatment } \\
\text { group was } 263 \text { days; } 8 \\
\text { days in control group; } \\
10 \text { patients underwent } \\
\text { second procedures } \\
\text { with varying results. }\end{array}$ & Positive short- term and long-term \\
\hline \multicolumn{6}{|l|}{ Lumbar Spine } \\
\hline $\begin{array}{l}\text { van Kleef et al (83) } \\
\text { Lumbar zygapophysial } \\
\text { joint radiofrequency } \\
\text { Randomized, placebo- } \\
\text { controlled, double-blind } \\
\text { trial } \\
\text { AHRQ Score - 9/10 } \\
\text { Cochrane Score - } 7 / 10\end{array}$ & $\begin{array}{l}31 \text { patients ( } 16 \text { in Con- } \\
\text { trol, } 15 \text { in Treatment) } \\
\text { with low back pain of } \\
\text { at least } 12 \text { months' du- } \\
\text { ration, confirmed by } \\
\text { diagnostic controlled } \\
\text { blocks. }\end{array}$ & $\begin{array}{l}\text { RF group lesion } 60 \\
\text { sec at } 80^{\circ} \mathrm{C} \text { of medial } \\
\text { branch; Control } \\
\text { group received sham } \\
\text { treatment with } \\
\text { electrode insertion. }\end{array}$ & $\begin{array}{l}2,3,6 \text { and } 12 \\
\text { months follow- } \\
\text { up. } \\
\text { Number of } \\
\text { successes, (> } 2 \text { pt } \\
\text { reduction VAS, > } \\
50 \% \text { Global and } \\
\text { Oswestry) }\end{array}$ & $\begin{array}{l}\text { Statistically higher } \\
\text { improvement in } \\
\text { treatment than control } \\
\text { at the indicated times } \\
\text { (e.g.; } 67 \% \text { treat, } 37 \% \\
\text { sham at } 2 \text { months). }\end{array}$ & Positive short- term and long-term \\
\hline
\end{tabular}

LeClaire et al (85), which appeared to be a well-performed, double-blind, placebo-controlled trial, had several deficiencies. This study failed to define the study population using appropriate diagnostic criteria. This was considered to be a major error, because patients were evaluated with a single diagnostic block and pain relief was considered to be more than one day's relief during the 7-day period following the diagnostic block. Consequently, any results or conclusions also would be erroneous. A study by Gallagher et al (84) was not included because it used the invalidated Shealy technique, failed to describe appropriate diagnostic techniques and outcome analysis, and it was not clear whether interventions were performed with fluoroscopy.

Three other studies were excluded from inclusion and evidence synthesis; one study used intraarticular facet joint denervation (86), which is not medial branch neurotomy and is of unclear clinical relevance, and the other two studies $(87,88)$ described radiofrequency lesioning of dorsal root ganglia.

There were 9 observational studies (89-97) identified that met inclusion criteria for the review. Of these, 4 (Table 8) evaluated cervical facet radiofrequency thermoneurolysis $(89,93,94,96)$ and 6 (Table 9) studies evaluated low back pain $(90,91,94-97) ; 2$ of the studies $(92,94)$ included evaluations of thoracic facet joint pain (Table 10). Some studies $(94,96)$ evaluated more than one level.

Among the 4 prospective trials, McDonald et al (93) and Sapir and Gorup (89) evaluated the effectiveness of cervical medial branch radiofrequency, whereas Dreyfuss et al (90) and Vad et al (97) evaluated the effectiveness of lumbar radiofrequency.

All of the studies evaluated pain relief. One study (90) evaluated multiple outcomes at 3,6, and 12 months. Two studies $(95,97)$ evaluated pain relief and function and a third study (96) evaluated pain relief, analgesic intake, and mood. Characteristics and results of observational studies of facet joint neurotomy, along with methodological criteria are described in Tables 8-10.

\section{Effectiveness}

Using the inclusion criteria, the studies by Lord et al (82) and van Kleef et al (83) were included for evidence synthesis. In addition, 4 prospective, non-randomized, observational studies by Dreyfuss et al (90), Sapir and Gorup (89), McDonald et al (93) and Vad et al (97) and 5 retrospective evaluations, by Stolker et al (92), Tzaan and Tasker (94), North et al (95) Schaerer (96) and Schofferman and Kine (91) were included in evidence synthesis.

Lord et al (82) evaluated percutaneous radiofrequency neurotomy for management of chronic cervical facet joint pain in a randomized, double blind, pla- cebo-controlled trial. They concluded that for patients with chronic cervical facet joint pain, confirmed by double-blinded, placebo-controlled local anesthetic blocks, percutaneous radiofrequency neurotomy with multiple lesions of target nerves can provide long lasting relief.

van Kleef et al (83) randomized 31 patients to radiofrequency neurolysis or sham lesioning of lumbar facet medial branch nerves. At 3, 6, and 12 months, there were statistically more successes in the treatment group than the sham group. These results demonstrated that radiofrequency denervation of the lumbar facet joints can be effective for pain reduction in patients with lumbar facet joint pain.

Among the non-randomized or observational studies, Dreyfuss et al (90) described lumbar facet joint radiofrequency neurotomy and found 60\% improvement in $80 \%$ of patients at 1 year. McDonald et al (93) determined the long-term efficacy of percutaneous radiofrequency medial branch neurotomy for the treatment of chronic neck pain in 28 patients diagnosed as having cervical zygapophysial joint pain, on the basis of controlled diagnostic blocks. They reported a median duration of relief after the first procedure of 219 days when failures were included, and 422 days when only the successes were considered. In addition, radiofrequency neurotomy of the cervical zygapophysial joints significantly reduced headache se- 
Table 8. Characteristics and results of observational studies of cervical medial branch neurotomy

\begin{tabular}{|c|c|c|c|c|c|}
\hline Study/Methods & Participants & Intervention(s) & Outcome(s) & Result(s) & Conclusion(s) \\
\hline & & & & \multicolumn{2}{|c|}{$\begin{array}{l}\text { Short-term relief }<3 \text { months } \\
\text { Long-term relief } \geq 3 \text { months }\end{array}$} \\
\hline $\begin{array}{l}\text { McDonald et al (93) } \\
\text { Prospective, non- } \\
\text { randomized } \\
\text { AHRQ Score - } 7 / 8\end{array}$ & $\begin{array}{l}28 \text { patients with cervical } \\
\text { facet pain diagnosed } \\
\text { by comparative local } \\
\text { anesthetic blocks. }\end{array}$ & $\begin{array}{l}\text { Cervical facet nerve } \\
\text { radiofrequency; } \\
\text { repeated when pain } \\
\text { returned. }\end{array}$ & $\begin{array}{l}\text { Pain relief and } \\
\text { duration of } \\
\text { benefit. }\end{array}$ & $\begin{array}{l}\text { Complete pain relief obtained } \\
\text { in } 71 \% \text { of patients after initial } \\
\text { procedure. Median duration } \\
\text { of relief was } 219 \text { days for all } \\
\text { patients; } 422 \text { days for initial } \\
\text { responders. }\end{array}$ & $\begin{array}{l}\text { Positive short- } \\
\text { term and long } \\
\text { term }\end{array}$ \\
\hline $\begin{array}{l}\text { Tzaan and Tasker (94) } \\
\text { Retrospective } \\
\text { AHRQ Score - 6/8 }\end{array}$ & $\begin{array}{l}118 \text { consecutive } \\
\text { procedures in } 90 \text { patients } \\
\text { diagnosed by local } \\
\text { anesthetic facet nerve } \\
\text { block. }\end{array}$ & $\begin{array}{l}\text { Radiofrequency facet } \\
\text { neurotomy at involved } \\
\text { levels. }\end{array}$ & Pain relief. & $\begin{array}{l}41 \% \text { of patients had }>50 \% \text { relief } \\
\text { at an average follow-up of } 5.6 \\
\text { months. }\end{array}$ & $\begin{array}{l}\text { Negative short- } \\
\text { term and long } \\
\text { term }\end{array}$ \\
\hline $\begin{array}{l}\text { Schaerer (96) } \\
\text { Retrospective } \\
\text { AHRQ Score - 6/8 }\end{array}$ & $\begin{array}{l}117 \text { patients with a total of } \\
50 \text { cervical procedures. }\end{array}$ & $\begin{array}{l}\text { Radiofrequency facet } \\
\text { neurotomy at involved } \\
\text { levels. }\end{array}$ & $\begin{array}{l}\text { Pain, analgesics } \\
\text { and mood. }\end{array}$ & $\begin{array}{l}50 \% \text { of } 50 \text { patients had }>50 \% \\
\text { pain relief, with average follow- } \\
\text { up of } 13.7 \text { months. }\end{array}$ & $\begin{array}{l}\text { Negative short- } \\
\text { term and long } \\
\text { term }\end{array}$ \\
\hline $\begin{array}{l}\text { Sapir and Gorup (89) } \\
\text { Prospective nonrandomized } \\
\text { AHRQ Score } \\
\text { 7/8 }\end{array}$ & $\begin{array}{l}46 \text { patients with cervical } \\
\text { whiplash symptoms } \\
\text { completed the study. } \\
\text { Litigant and non-litigant } \\
\text { patients were included. }\end{array}$ & $\begin{array}{l}\text { The 2-phase diagnostic } \\
\text { cervical medial branch } \\
\text { blocks, followed } \\
\text { by radiofrequency } \\
\text { neurotomy. }\end{array}$ & $\begin{array}{l}\text { VAS and } \\
\text { self-report of } \\
\text { improvement } \\
\text { (SRI) }\end{array}$ & $\begin{array}{l}\text { The difference between groups } \\
\text { in the degree of symptomatology } \\
\text { or response to treatment did not } \\
\text { reach significance. }\end{array}$ & $\begin{array}{l}\text { Positive short } \\
\text { and long-term }\end{array}$ \\
\hline
\end{tabular}

Table 9. Characteristics and results of observational studies of lumbar medial branch neurotomy

\begin{tabular}{|c|c|c|c|c|c|}
\hline Study/Methods & Participants & Intervention(s) & Outcome(s) & Result(s) & Conclusion(s) \\
\hline & & & & \multicolumn{2}{|c|}{$\begin{array}{l}\text { Short-term relief }<3 \text { months } \\
\text { Long-term relief } \geq 3 \text { months }\end{array}$} \\
\hline $\begin{array}{l}\text { Dreyfuss et al (90) } \\
\text { Prospective nonrandomized } \\
\text { AHRQ Score } \\
8 / 8\end{array}$ & $\begin{array}{l}15 \text { patients with } \\
\text { chronic lumbar facet } \\
\text { pain diagnosed by } \\
\text { comparative local } \\
\text { anesthetic blocks. }\end{array}$ & $\begin{array}{l}\text { Lumbar } \\
\text { radiofrequency; EMG } \\
\text { of multifidus muscle } \\
\text { used to determine } \\
\text { accuracy of neurotomy. }\end{array}$ & $\begin{array}{l}\text { Pain relief, } \\
\text { functions, EMG } \\
\text { at } 6 \text { weeks; pain } \\
\text { relief \& outcomes } \\
\text { assessment at } 3,6 \text {, } \\
\text { and } 12 \text { months. }\end{array}$ & $\begin{array}{l}60 \% \text { of patients obtained at least } \\
90 \% \text { relief of pain at } 12 \text { months, } \\
\text { and } 87 \% \text { at least } 60 \% \text { relief at } \\
12 \text { months. }\end{array}$ & $\begin{array}{l}\text { Positive short- } \\
\text { term and long } \\
\text { term }\end{array}$ \\
\hline $\begin{array}{l}\text { Schofferman and Kine (91) } \\
\text { Retrospective } \\
\text { AHRQ Score - } 7 / 8\end{array}$ & $\begin{array}{l}20 \text { patients underwent } \\
\text { repeat radiofrequency } \\
\text { neurotomy. Medial } \\
\text { branch blocks used for } \\
\text { initial diagnosis. }\end{array}$ & $\begin{array}{l}\text { Radiofrequency } \\
\text { neurotomy of the } \\
\text { lumbar facets; repeated } \\
\text { as indicated clinically. }\end{array}$ & Pain relief. & $\begin{array}{l}\text { Mean duration of relief of initial } \\
\text { RF was } 10.5 \text { months. Second } \\
\text { treatment effective in } 85 \% \text {; } \\
\text { mean duration of relief of } 11.6 \\
\text { months. }\end{array}$ & $\begin{array}{l}\text { Positive short- } \\
\text { term and long } \\
\text { term }\end{array}$ \\
\hline $\begin{array}{l}\text { Vad et al (97) } \\
\text { Prospective nonrandomized } \\
\text { AHRQ Score - } 8 / 8\end{array}$ & $\begin{array}{l}12 \text { patients with sports- } \\
\text { related low back pain } \\
\text { diagnosed with medial } \\
\text { branch blocks. }\end{array}$ & $\begin{array}{l}\text { Radiofrequency } \\
\text { neurotomy of the } \\
\text { lumbar facets. }\end{array}$ & $\begin{array}{l}\text { Pain relief } \\
\text { and return to } \\
\text { pretreatment level } \\
\text { of function. }\end{array}$ & $\begin{array}{l}\text { Mean duration of pain relief: } \\
1.3 \text { years. } 83 \% \text { of patients } \\
\text { returned to pretreatment level } \\
\text { of function. }\end{array}$ & $\begin{array}{l}\text { Positive short- } \\
\text { term and long } \\
\text { term }\end{array}$ \\
\hline $\begin{array}{l}\text { North et al (95) } \\
\text { Retrospective } \\
\text { AHRQ Score - 7/8 }\end{array}$ & $\begin{array}{l}82 \text { patients with lumbar } \\
\text { pain of facet origin } \\
\text { diagnosed by facet nerve } \\
\text { blocks. }\end{array}$ & $\begin{array}{l}\text { Radiofrequency } \\
\text { neurotomy of the } \\
\text { lumbar facets for } 42 \\
\text { patients. }\end{array}$ & $\begin{array}{l}\text { Pain relief and } \\
\text { function. }\end{array}$ & $\begin{array}{l}45 \% \text { of patients with } \\
\text { radiofrequency reported }>50 \% \\
\text { pain relief at } 2 \text { years. }\end{array}$ & $\begin{array}{l}\text { Negative short- } \\
\text { term and long } \\
\text { term }\end{array}$ \\
\hline $\begin{array}{l}\text { Tzaan and Tasker }(94) \\
\text { Retrospective } \\
\text { AHRQ Score - } 6 / 8\end{array}$ & $\begin{array}{l}90 \text { patients diagnosed by } \\
\text { local anesthetic blocks. }\end{array}$ & $\begin{array}{l}\text { Radiofrequency facet } \\
\text { neurotomy at involved } \\
\text { levels. }\end{array}$ & Pain relief. & $\begin{array}{l}41 \% \text { of patients had }>50 \% \text { relief } \\
\text { at an average follow-up of } 5.6 \\
\text { months. }\end{array}$ & $\begin{array}{l}\text { Negative short- } \\
\text { term and long } \\
\text { term. }\end{array}$ \\
\hline $\begin{array}{l}\text { Schaerer (96) } \\
\text { Retrospective } \\
\text { AHRQ Score - 6/8 }\end{array}$ & $\begin{array}{l}117 \text { patients } \\
71 \text { lumbar procedures }\end{array}$ & $\begin{array}{l}\text { Radiofrequency facet } \\
\text { neurotomy at involved } \\
\text { levels. }\end{array}$ & $\begin{array}{l}\text { Pain, analgesics } \\
\text { and mood. }\end{array}$ & $\begin{array}{l}35 \% \text { of } 71 \text { lumbar RF had }>50 \% \\
\text { pain relief, with average follow- } \\
\text { up of } 13.7 \text { months. }\end{array}$ & $\begin{array}{l}\text { Negative short- } \\
\text { term and long } \\
\text { term }\end{array}$ \\
\hline
\end{tabular}


Table 10. Characteristics and results of observational studies of thoracic medial branch neurotomy

\begin{tabular}{|c|c|c|c|c|c|}
\hline Study/Methods & Participants & Intervention(s) & Outcome(s) & \multicolumn{2}{|c|}{$\begin{array}{l}\text { Short-term relief }<3 \text { months } \\
\text { Long-term relief } \geq 3 \text { months }\end{array}$} \\
\hline $\begin{array}{l}\text { Stolker et al (92) } \\
\text { Retrospective } \\
\text { AHRQ Score - } 7 / 8\end{array}$ & $\begin{array}{l}40 \text { patients with chronic } \\
\text { thoracic facet pain diagnosed } \\
\text { with medial branch block. }\end{array}$ & $\begin{array}{l}\text { Thoracic radiofrequency } \\
\text { facet neurotomy. }\end{array}$ & Pain relief. & $\begin{array}{l}\text { At an average followup } \\
\text { of } 31 \text { months, } 83 \% \text { had } \\
>50 \% \text { relief. }\end{array}$ & $\begin{array}{l}\text { Positive short-term } \\
\text { and long term }\end{array}$ \\
\hline $\begin{array}{l}\text { Tzaan and Tasker (94) } \\
\text { Retrospective } \\
\text { AHRQ Score - } 6 / 8\end{array}$ & $\begin{array}{l}90 \text { consecutive patients } \\
\text { diagnosed by local anesthetic } \\
\text { facet nerve block. }\end{array}$ & $\begin{array}{l}\text { Radiofrequency facet } \\
\text { neurotomy at involved levels. }\end{array}$ & Pain relief. & $\begin{array}{l}41 \% \text { of patients had } \\
>50 \% \text { relief at an } \\
\text { average follow-up of } \\
5.6 \text { months. }\end{array}$ & $\begin{array}{l}\text { Negative short-term } \\
\text { and long term }\end{array}$ \\
\hline
\end{tabular}

verity in $80 \%$ of patients, both at shortterm and long-term follow-up.

Among the retrospective evaluations, Tzaan and Tasker (94) evaluated 118 consecutive percutaneous radiofrequency facet rhizotomies performed on 90 patients for cervical, thoracic and lumbar pain. They reported that with the first procedure, greater than $50 \%$ subjective reduction of pain was present in $41 \%$ of patients. They included cervical, thoracic and lumbosacral facets and noted no significant difference between unilateral or bilateral involvement. North et al (95) evaluated radiofrequency lumbar facet denervation with long-term outcome assessment by a disinterested third party interview. Forty-five percent of patients undergoing denervation reported at least $50 \%$ relief of pain at long-term follow-up. Schaerer (96) evaluated the value of radiofrequency facet rhizotomy in the treatment of patients with chronic neck and low back pain problems in 90 consecutive patients, undergoing 117 procedures. They reported that overall results were good to excellent in $50 \%$ of the patients in cervical spine and $35 \%$ in lumbar spine with an average follow-up time of 13.7 months. Schofferman and Kine (91) demonstrated that radiofrequency neurolysis can be repeated when pain returns, re-establishing long-term pain relief in $85 \%$ of patients.

Criticisms faced by these trials include the overall relatively small number of patients. The total number of patients combined for cervical and lumbar regions in the randomized trials was 27 in the treatment groups, compared to 28 in the control groups. Consequently, the number of patients undergoing a cervical or lumbar intervention is small. An additional criticism for van Kleef's et al's (83) study is that they included patients after a single diagnostic block, which increases the false-positive rate.

\section{Level of Evidence}

Evidence for radiofrequency neurotomy was Level III to Level II, moderate to strong for short-term and long-term relief of lumbar and cervical facet joint pain.

\section{Safety and Complications}

Our search strategy yielded 246 articles regarding spinal injections. The most common and worrisome complications of facet joint interventions are related to needle placement and drug administration. Potential complications include dural puncture, spinal cord trauma, infection, intraarterial or intravenous injection, spinal anesthesia, chemical meningitis, neural trauma, pneumothorax, radiation exposure, facet capsule rupture, hematoma formation, and steroid side effects (98-114). The risks associated with needle injections may be higher in the cervical spine, particularly with intraarticular facet joint injections, and perhaps particulate steroid injections into vessels in the neck, given the proximity of the cervical spinal cord. However, quantitative data are lacking.

Potential side effects with radiofrequency denervation include painful $\mathrm{cu}$ taneous dysesthesias, increased pain due to neuritis or neurogenic inflammation, anesthesia dolorosa, cutaneous hyperesthesia, pneumothorax and deafferentation pain. Unintentional damage to a spinal nerve during medial branch radiofrequency, causing a motor deficit, is also a possible complication of the neurolytic procedure.

Data regarding the incidence or prevalence of complications are sparse, with respect to specific complications with intraarticular facet joint injections and medial branch blocks. A retrospective chart review of patients undergoing radiofrequency neurotomy for facet joint pain over a five-year period provides some data regarding the complication rates associated with the procedure (113). Kornick et al (113) reported six minor complications with radiofrequency neurolysis in the lumbar spine. During 116 separate denervation procedures, 6 minor complications were noted, including 3 cases of localized pain lasting > 2 weeks and 3 cases of neuritic pain lasting $<2$ weeks. There were no cases of infection or new sensory or motor deficits. The overall rate of complications, which were minor, was $1 \%$.

\section{DISCUSSION}

Several systematic and narrative reviews have evaluated facet joint interventions. However, none of the systematic evaluations included all three interventions, independently or in combination in their evidence synthesis. Nelemans et al (65) reviewed intraarticular injections in a systematic review and provided a negative opinion. Intraarticular injections also have been evaluated in non-systematic reviews. Medial branch blocks have not been systematically evaluated for their therapeutic effectiveness.

Nelemans et al (65) performed a partial review of intraarticular injections showing negative effects. Slipman et al (64) also analyzed the effectiveness of intraarticular injections for the low 
back only, however, it is not clear whether or not the study was a systematic review. Their conclusions were more favorable for intraarticular injections in the lumbar spine in managing low back pain. Manchikanti et al (4) also reviewed the effectiveness of intraarticular injections during the preparation of interventional pain management guidelines. However, the guidelines are not considered to be a systematic review.

Regarding radiofrequency, there have been 3 systematic reviews and a critical review by Slipman et al (64) of medial branch neurotomy. Geurts et al's (60) systematic review included only randomized controlled trials and included 6 studies, two of which were dorsal root ganglion radiofrequency lesioning studies, and a third involved intraarticular facet denervation. The remaining 3 studies involved medial branch radiofrequency lesioning. Two of the studies involved lumbar and one study involved cervical radiofrequency lesioning. In the abstract section of the paper, the authors stated that "All studies, whether high or low quality, reported positive outcomes." Of the two lumbar medial branch radiofrequency lesioning studies, the study by van Kleef et al (83) was rated as high quality and the one by Gallagher et al (84) was rated as low quality and both were positive studies. By the "Best Synthesis Method" of Slavin (115), this combination of one positive high quality and one additional positive low quality study assigned the level of "Moderate Evidence" to the efficacy of radiofrequency lesioning in the lumbar region. However, the positive study by Lord et al (82) involving cervical radiofrequency lesioning in whiplash patients was rated as high quality, but using the "best synthesis method" the authors concluded that there was limited evidence "that pain complaints in whiplash patients can be treated by RF denervation of cervical zygapophysial joints," because it was a solitary study and the "Best synthesis method" required at least one more study of low quality to reach the level of "Moderate Evidence" or one additional high quality study to reach to the level of "Strong Evidence." The review by Geurts et al (60) has been the subject of criticism for inappropriate methodology and inaccurate conclusions (116118)

The review by Manchikanti et al (63) argued that restricting analysis of the efficacy of an intervention to only ran- domized controlled trials ignores a large body of accumulated evidence about the intervention. Thus, both randomized controlled trials and observational studies were subjected to rigorous analysis for quality using criteria described in an Agency for Healthcare Research and Quality (AHRQ) publication (66). Based on stringent criteria, Manchikanti et al (67) identified 7 randomized trials of radiofrequency neurotomy for spinal pain, of which 4 related to medial branch neurotomy. One of these 4 studies was by LeClaire et al (85). Two of these four studies were excluded in the evidence synthesis analysis due to study deficiencies. The study by LeClaire et al (85) was excluded due to failure to meet the AHRQ criteria for inclusion. The criteria stated by the authors were "patients 18-65 years of age who had experienced significant relief of their low back pain for at least 24 hours during the week after intraarticular facet injections under fluoroscopy using Omnipaque ( $240 \mathrm{mg}, 0.3 \mathrm{~mL}$ ), as reported by the patient and the physiatrist. The medication used was lidocaine hydrochloride $2 \%$ without epinephrine $(0.5 \mathrm{~mL})$ and triamcinolone acetonide $(40 \mathrm{mg}, 0.5 \mathrm{~mL})$." Thus, a method lacking validation was employed to select patients for randomization to active treatment or placebo treatment. The study by Gallagher et al (84) was excluded because it used the invalidated Shealy technique and important aspects, such as effects on physical impairment and disability were not investigated. Manchikanti et al (63) included for evidence synthesis studies by Lord et al (82) and van Kleef et al (83) and 4 prospective evaluations and 3 retrospective evaluations. They excluded numerous studies that failed to meet inclusion criteria.

The review by Niemisto et al (61) included only randomized controlled trials and was based on current recommendations of the Cochrane Collaboration Back Review Group. Seven randomized controlled trials were identified as meeting the criteria and were included in the analysis, including 2 trials involving radiofrequency lesioning of the dorsal root ganglion for cervicobrachial pain and 1 trial involving a solitary central intradiscal radiofrequency lesion for discogenic pain. Of the 4 trials involving radiofrequency lesioning of the medial branches, 1 was cervical (82) and 3 were lumbar (82-84). Qualitative analysis was performed, assigning the evidence of effica- cy for the intervention to 1 of 4 levels of evidence, Level A (Strong), Level B (Moderate), Level C (Limited) and Level D (no evidence). The cervical radiofrequency lesioning study by Lord et al (82) was reviewed in detail. The reviewers rated the study as high quality and noted that $7 / 12$ patients in the treatment group and only $1 / 12$ patients in the control group were pain free at 27 weeks post-lesioning and that the median time to return of $50 \%$ of the preoperative pain level was 263 days in the intervention group and only 8 days in the control group. Despite this, Niemisto et al (61) concluded that there was only "limited" (level C) evidence that radiofrequency lesioning "had a positive shortterm effect on chronic cervical zygapophysial joint pain" because it was a singular study and lacked the corroboration needed to reach a Level B (moderate - 1 high quality plus 1 or more low quality studies) or Level A (strong - multiple high quality studies) classification of evidence.

Despite problems with the studies of LeClaire et al (85) and Gallagher et al (84) noted previously, Niemisto et al (61) chose to include them in their analysis. Utilizing their criteria, they concluded that radiofrequency denervation had a positive short-term effect in van Kleef et al (83), a neutral effect in LeClaire et al (85), and considered the findings of Gallagher et al (84) unclear, "because they did not include an intention-to-treat analysis." Thus, Niemisto et al (61) concluded that evidence of short-term effect was conflicting.

We observe, similar to Geurts et al (60) that Niemesto et al (61) utilized inconsistent methodology, did not exclude 2 studies performed inappropriately (84, 85 ), and arrived at conflicting conclusions. Even though the review was described as being within the framework of Cochrane Collaboration Back Review Group guidelines, the conclusions may have been unwarranted.

The review by Slipman et al (64) was limited to intraarticular injections and radiofrequency lesioning of medial branch nerves in the lumbar spine. They reviewed 15 studies that discussed radiofrequency neurotomy, and out of these, selected 4 prospective studies for analysis, including randomized controlled trials by van Kleef et al (83), LeClaire et al (85) and Gallagher et al (84), and the case series by Dreyfuss et al (90), a prospective, observational study. The authors remarked that "each 
study reported a positive response to the RF treatment." They noted that "Gallagher et al (84) in their abstract mentioned that the solution used for the initial diagnostic injection was a combination of local anesthetic and steroid, whereas the main text of the paper states that the solution used was only local anesthetic." The study by van Kleef et al (83) was criticized for patient selection on the basis of a single positive diagnostic block "which as discussed previously, is known to have a false positive rate of approximately $38 \%$ ", and the fact that "the technique may have been in error, because he placed the electrodes at an angle to the target nerve" rather than orienting electrodes parallel to the nerve, as has been shown to be of theoretical advantage in laboratory studies. They also noted that LeClaire et al (85) used the inclusion criterion of significant relief of low back pain for at least 24 hours during the week after the diagnostic facet block. The study was further criticized for the use of the Roland Morris score as an important outcome measure, which describes functional limitation and not pain relief. Despite the criticisms noted, they rated the evidence in favor of radiofrequency lesioning of the medial branches for low back pain at Level 3, Moderate.

In contrast to previous systematic reviews, the present systematic review has several additional features: facet joint interventions involving cervical, thoracic, and lumbar facet joints were evaluated; randomized and observational studies were taken into consideration; the review was performed by physicians who perform these procedures, although none of the reviewed studies were conducted by these physicians.

In the present systematic review, regarding intraarticular facet joint injections, only the randomized trial of lumbar spine pain by Carette et al (68) may be considered to be positive (albeit controversial), with only a $42 \%$ success rate. In contrast, the second randomized trial of cervical spine pain following whiplash injury by Barnsley et al (72), was negative. Among the non-randomized trials, positive results were noted for short-term relief in 4 of the 5 studies; however, longterm relief was noted only in 3 of the 5 studies. The evidence was moderate for short-term and long-term pain relief with intraarticular lumbar facet joint injections. However, the only randomized trial of cervical spine facets was negative, with no observational studies available. Consequently, evidence for cervical facet joint injections was negative.

The evidence was moderate for short-term and long-term pain relief with lumbar and cervical medial branch blocks in managing chronic low back and neck pain.

Regarding radiofrequency neurotomy, there was one properly designed randomized, controlled trial, each, for cervical and lumbar regions. However, the number of patients was small. Additional evidence was provided by mixed positive short-term and long-term results from observational studies. The evidence for radiofrequency neurotomy was moderate to strong for short-term and longterm pain relief of lumbar and cervical facet joint pain.

\section{ConcLusion}

Based on a systematic review of the studies described herein, with intraarticular facet joint injections there was moderate evidence for short-term and long-term relief of chronic lumbar facet pain, and negative evidence for cervical facet joint injections. For medial branch blocks there was moderate evidence in managing lumbar and cervical facet joint pain. For radiofrequency facet neurolysis there was moderate to strong evidence for short-term and long-term relief of lumbar and cervical facet joint pain.

Appendix A. Methodologic quality criteria list (key items of internal validity) of Cochrane Musculoskeletal Review Group (67)

\section{Patient selection}

\section{Treatment allocation}

Was the method of randomization described and adequate?

Was the treatment allocation concealed?

2. Were the groups similar at baseline regarding the most important prognostic indicators?

\section{Intervention}

3. Was the care provider blinded?

4. Was controlled for co-interventions which could explain the results?
5. Was the compliance rate (each group) unlikely to cause bias?

6. Was the patient blinded?

\section{Outcome measurement}

7. Was the outcome assessor blinded?

8. Was at least one of the primary outcome measures applied?

9. Was the withdrawal/drop-out rate unlikely to cause bias?

\section{Statistics}

10. Did the analysis include an intention-to-treat analysis?

Appendix B. General Inclusion/ exclusion criteria (61)

1. Are the patients described in sufficient detail to allow you to decide whether they are comparable to those that are seen in clinical practices of interventional pain management?

A) Setting - office, hospital, outpatient, inpatient

B) Physician - interventional pain physician, general physician, anesthesiologist, physiatrist, neurologist, rheumatologist, orthopedic surgeon, neurosurgeon, etc.

C) Patient characteristics - duration of pain

D) Non-interventional techniques or surgical intervention in the past

E) Additional exclusion criteria

F) Additional inclusion criteria

2. Is the intervention described adequately to enable you to provide the same treatment for patients in interventional pain management settings?

A) Nature of intervention

B) Frequency of intervention

C) Duration of intervention

3. Were clinically relevant outcomes measured?

A) Proportion of pain relief

B) Disorder/specific disability

C) Functional improvement

D) Allocation of eligible and non-eligible patients to return to work

E) Ability to work

F) Psychological assessment or improvement 
Author AfFiliation:

Mark V. Boswell, MD, PhD

Associate Professor of Anesthesiology

Chief, Pain Medicine Service

Director, Pain Medicine Fellowship

Department of Anesthesiology

University Hospitals of Cleveland

Case School of Medicine

11100 Euclid Avenue

Cleveland $\mathrm{OH} 44106$

E-mail: boswellmv@earthlink.net

\section{James D. Colson, MS, MD}

Clinical Assistant Professor of

Anesthesiology

Attending Staff, Center for

Interventional Pain Medicine

University Of Michigan

1H247 UH, 1500 E. Medical Center

Drive

Ann Arbor, MI 48130

E-mail: colsonj@umich.edu

\section{William F. Spillane, MD}

Anesthesiology/Neurology

Medical Director, Pain Control Center

Co-Director, Pain Fellowship Program

Assistant Clinical Professor

Department Of Anesthesiology

Wake Forest University Baptist Medical

Center

Medical Center Boulevard

Winston-Salem, NC 27157

E-mail: wspillan@wfubmc.edu

\section{REREFERENCES}

1. Goldthwait JE. The lumbosacral articulation: An explanation of many cases of lumbago, sciatica, and paraplegia. Boston Med and Surg J 1911; 164:365-372.

2. Bogduk N. International Spinal Injection Society guidelines for the performance of spinal injection procedures. Part 1: Zygapophysial joint blocks. Clin J Pain; 1997; 13:285-302.

3. Boswell M, Singh V, Staats P, Hirsch JA. Ac curacy of precision diagnostic blocks in the diagnosis of chronic spinal pain of facet or zygapophyseal joint origin: A systematic review. Pain Physician 2003; 6:449456.

4. Manchikanti L, Staats PS, Singh V, Schultz DM, Vilims BD, Jasper JF, Kloth DS, Trescot AM, Hansen HC, Falasca TD, Racz GB, Deer T, Burton AW, Helm S, Lou L, Bakhit CE, Dunbar EE, Atluri SL, Calodney AK, Hassenbusch S, Feler CA. Evidence-based practice guidelines for interventional techniques in the management of chronic spinal pain. Pain Physician 2003; 6:3-80.
5. Pang WW, Mok MS, Lin ML, Chang DP, Hwang MH. Application of spinal pain mapping in the diagnosis of low back pain-analysis of 104 cases. Acta Anaesthesiol Sin 1998; 36:71-74.

6. Manchikanti L, Singh V, Pampati V, Damron KS, Barnhill RC, Beyer CD, Cash KA. Evaluation of the relative contributions of various structures in chronic low back pain. Pain Physician 2001; 4:308-316.

7. Fukui S, Ohseto K, Shiotani M, Ohno K, Karasawa H, Naganuma Y, Yuda Y. Referred pain distribution of the cervical zygapophyseal joints and cervical dorsal rami. Pain 1996; 68:79-83.

8. Dwyer A, Aprill C, Bogduk N. Cervical zygapophyseal joint pain patterns. I: A study in normal volunteers. Spine 1990; 15:453457.

9. Aprill C, Dwyer A, Bogduk N. The prevalence of cervical zygapophyseal joint pain patterns. II: A clinical evaluation. Spine 1990; 15:458-461.

10. Pawl RP. Headache, cervical spondylosis, and anterior cervical fusion. Surg Ann 1977; 9:391-498.

11. Windsor RE, Nagula D, Storm S. Electrical stimulation induced cervical medial branch referral patterns. Pain Physician.2003; 6:411-418.

12. Dreyfuss P, Tibiletti C, Dreyer SJ. Thoracic zygapophyseal joint pain patterns: A study in normal volunteers. Spine 1994; 19:807-811.

13. Mooney V, Robertson J. The facet syndrome. Clin Orthop 1976; 115:149-156.

14. McCall IW, Park WM, O’Brien JP. Induced pain referral from posterior elements in normal subjects. Spine 1979; 4:441-446.

15. Marks R. Distribution of pain provoked from lumbar facet joints and related structures during diagnostic spinal infiltration. Pain 1989; 39:37-40.

16. Fukui S, Ohseto K, Shiotani M, Ohno K, Karasawa H, Naganuma Y. Distribution of referral pain from the lumbar zygapophyseal joints and dorsal rami. Clin J Pain 1997; 13:303-307.

17. Hirsch C, Ingelmark BE, Miller M. The anatomical basis for low back pain. Acta Orthop Scand 1963; 33:1-17.

18. Windsor RE, King FJ, Roman SJ, Tata NS, Cone-Sullivan LA, Thampi S, Acebey M, Gilhool JJ, Rao R, Sugar R. Electrical stimulation induced lumbar medial branch referral patterns. Pain Physician 2002; 5 : 347-353.

19. Bogduk N. The clinical anatomy of the cervical dorsal rami. Spine 1982; 7:319-330.

20. Jackson HC, Winkelmann RK, Bickel WH. Nerve endings in the human lumbar spinal column and related structures. J Bone Joint Surg AM 1966; 48A:1272-1281.

21. Cavanaugh JM, Ozaktay AC, Yamashita HT, King Al. Lumbar facet pain: Biomechanics, neuroanatomy, and neurophysiology. J Biomech 1996; 29:1117-1129.

22. Bogduk N, Wilson AS, Tynan W. The hu- man lumbar dorsal rami. J Anat 1982; 134: 383-397.

23. Suseki K, Takahashi Y, Takahashi K et al. Innervation of the lumbar facet joints. Spine 1997; 22:477-485.

24. Bogduk N. The innervation of the lumbar spine. Spine 1983; 8:286-293.

25. Chua WH, Bogduk N. The surgical anatomy of thoracic facet denervation. Acta Neurochir 1995; 136:140-144.

26. Stilwell DL. The nerve supply of the vertebral column and its associated structures in the monkey. Anat Rec 1956; 125:139169.

27. Zhang J, Tsuzuki N, Hirabayashi S, Saiki K Fujita K. Surgical anatomy of the nerves and muscles in the posterior cervical spine: a guide for avoiding inadvertent nerve injuries during the posterior approach. Spine 2003; 28:1379-1384.

28. Dreyfuss P, Schwarzer AC, Lau P, Bogduk $N$. Specificity of lumbar medial branch and L5 dorsal ramus blocks. Spine 1997; 22:895-902.

29. Kaplan M, Dreyfuss P, Halbrook B, Bogduk $N$. The ability of lumbar medial branch blocks to anesthetize the zygapophysial joint. Spine 1998; 23:1847-1852.

30. Barnsley L, Bogduk N. Medial branch blocks are specific for the diagnosis of cervical zygapophyseal joint pain. Reg Anesth 1993; 18:343-350.

31. Jackson RP, Jacobs RR, Montesano PX. Facet joint injection in low back pain. A prospective statistical study. Spine 1988; 13:966-971.

32. Jackson RP. The facet syndrome: Myth or reality? Clin Orthop 1992; 279:110-121.

33. Deyo RA. Fads in the treatment of low back pain. N Engl J Med 1991; 325:1039-1040.

34. Ferrari R. Letter to the editor. Spine 2002; 27:327-328.

35. Bogduk N, Holmes S. Controlled zygapophysial joint blocks: The travesty of cost-effectiveness. Pain Med 2000; 1:2434 .

36. Schwarzer AC, Wang S, O'Driscoll, Harrington T, Bogduk N, Laurent R. The ability of computed tomography to identify a painful zygapophysial joint in patients with chronic low back pain. Spine 1995; 20:907-912.

37. Schwarzer AC, Aprill CN, Derby R, Fortin J, Kine G, Bogduk N. Clinical features of patients with pain stemming from the lumbar zygapophysial joints. Is the lumbar facet syndrome a clinical entity? Spine 1994; 19: 1132-1137.

38. Manchikanti L, Pampati V, Fellows B, Baha A. The inability of the clinical picture to characterize pain from facet joints. Pain Physician 2000; 3:158-166.

39. Schwarzer AC, Derby R, Aprill CN, Fortin J, Kine G, Bogduk N. The value of the provocation response in lumbar zygapophysial joint injections. Clin J Pain 1994; 10:309313.

40. Barnsley L, Lord S, Bogduk N. Compara- 
tive local anesthetic blocks in the diagnosis of cervical zygapophysial joints pain. Pain 1993; 55:99-106.

41. Lord SM, Barnsley L, Bogduk N. The utility of comparative local anesthetic blocks versus placebo-controlled blocks for the diagnosis of cervical zygapophysial joint pain. Clin J Pain 1995; 11:208-213.

42. Revel ME, Listrat VM, Chevalier XJ, Dougados M, N'guyen MP, Vallee C, Wybier M, Gires F, Amor B. Facet joint block for low back pain: Identifying predictors of a good response. Arch Phys Med Rehabil 1992; 73: 824-828.

43. Revel M, Poiraudeau S, Auleley GR, Payan C, Denke A, Nguyen M, Chevrot A, Fermanian J. Capacity of the clinical picture to characterize low back pain relieved by facet joint anesthesia. Proposed criteria to identify patients with painful facet joints. Spine 1998; 23:1972-1977.

44. Schwarzer AC, Derby R, Aprill CN, Fortin J, Kine $G$, Bogduk N. Pain from the lumbar zygapophysial joints: A test of two models. J Spinal Disord 1994; 7:331-336.

45. Laslett M, Oberg B, Aprill CN, McDonald B. Zygapophysial joint blocks in chronic low back pain; a test of Revel's model as a screening test. BMC Musculoskelet Disord. 2004; 5:43.

46. Manchikanti L, Pampati VS, Fellows B, Pakanati RR. Prevalence of lumbar facet joint pain in chronic low back pain. Pain Physician 1999; 2:59-64.

47. Manchikanti L, Pampati VS, Fellows B, Bakhit CE. The diagnostic validity and therapeutic value of lumbar facet joint nerve blocks with or without adjuvant agents. Cur Rev Pain 2000; 4:337-344.

48. Bogduk N. Low back pain. In Clinical Anatomy of the Lumbar Spine and Sacrum, ed 3.Churchill Livingstone, New York, 1997; pp 187-214.

49. Bogduk N, Lord S. Cervical zygapophysial joint pain. Neurosurgery 1998; 8:107-117.

50. Aprill C, Bogduk N. The prevalence of cervical zygapophyseal joint pain. Spine 1992; 17:744-747.

51. Barnsley L, Lord S, Wallis B, Bogduk N. False-positive rates of cervical zygapophysial joint blocks. Clin J Pain 1993; 9:124130.

52. Schwarzer AC, Aprill CN, Derby R, Fortin J, Kine $G$, Bogduk N. The false positive rate of uncontrolled diagnostic blocks of the lumbar zygapophysial joints. Pain 1994; 58:195-200.

53. Schwarzer AC, Wang SC, Bogduk N, MCNaught PJ, Laurent R. Prevalence and clinical features of lumbar zygapophysial joint pain: A study in an Australian population with chronic low back pain. Ann Rheum Dis 1995; 54:100-106.

54. Manchikanti L, Boswell MV, Singh V, Pampati V, Damron KS, Beyer CD. Prevalence of facet joint pain in chronic spinal pain of cervical, thoracic, and lumbar regions. BMC Musculoskelet Disord 2004; 5:15.

55. Barnsley L, Lord SM, Wallis BJ, Bogduk
$N$. The prevalence of chronic cervical zygapophyseal joint pain after whiplash. Spine 1995; 20:20-26.

56. Lord SM, Barnsley L, Wallis BJ, Bogduk N. Chronic cervical zygapophysial joint pain after whiplash: A placebo-controlled prevalence study. Spine 1996; 21:1737-1745.

57. Manchikanti L, Singh V, Rivera J, Pampati V. Prevalence of cervical facet joint pain in chronic neck pain. Pain Physician 2002; 5 : 243-249.

58. Manchikanti L, Pampati V, Beyer CD, Damron KS. Evaluation of the prevalence of thoracic facet joint pain in chronic thoracic pain. Pain Physician2002; 5:354-359.

59. Merskey H, Bogduk N. Classification of chronic pain: Descriptions of chronic pain syndromes and definitions of pain terms. Second Edition. IASP Press, Seattle, 1994.

6o. Geurts JW, van Wijk RM, Stolker RJ, Groen GJ. Efficacy of radiofrequency procedures for the treatment of spinal pain: A systematic review of randomized clinical trials. Reg Anesth Pain Med 2001; 26:394-400.

61. Niemisto L, Kalso E, Malmivaara A, Seitsalo S, Hurri H, Cochrane Collaboration Back Review Group. Radiofrequency denervation for neck and back pain: a systematic review within the framework of the Cochrane collaboration back review group. Spine 2003, 28:1877-1888.

62. Dreyfuss PH, Dreyer SJ. Lumbar zygapophysial (facet) joint injections. Spine J 2003; 3:50S-59S.

63. Manchikanti L, Singh V, Vilims BD, Hansen HC, Schultz DM, Kloth DS. Medial branch neurotomy in management of chronic spinal pain: Systematic review of the evidence. Pain Physician2002; 5:405-418.

64. Slipman CW, Bhat AL, Gilchrist RV, Issac Z, Chou L, Lenrow DA. A critical review of the evidence for the use of zygapophysial injections and radiofrequency denervation in the treatment of low back pain. Spine J 2003; 3:310-316.

65. Nelemans PJ, deBie RA, deVet HC, Sturmans F. Injection therapy for subacute and chronic benign low back pain. Spine 2001; 26:501-515.

66. West S, King V, Carey TS, Lohr KN, McKoy $N$, Sutton SF, Lux L. Systems to rate the strength of scientific evidence. Evidence Report/Technology Assessment No. 47 University of North Carolina: Agency for Healthcare Research and Quality. AHRQ Publication No. 02-E016; April 2002.

67. van Tulder M, Assendelft W, Koes B, Bouter LM. Method guidelines for systematic reviews in the Cochrane Collaboration Back Review Group for Spinal Disorders. Spine 1997; 22:2323-2330.

68. Carette S, Marcoux S, Truchon R, Grondin C, Gagnon J, Allard Y, Latulippe M. A controlled trial of corticosteroid injections into facet joints for chronic low back pain. N Engl J Med 1991; 325:1002-1007.

69. Lilius G, Laasonen EM, Myllynen P, Harilainen A, Gronlund G. Lumbar facet joint syndrome. A randomized clinical tri- al. J Bone Joint Surg (Br) 1989; 71:681-684.

70. Marks RC, Houston T, Thulbourne T. Facet joint injection and facet nerve block. A randomized comparison in 86 patients with chronic low back pain. Pain 1992; 49: 325-328.

71. Nash TP. Facet joints. Intra-articular steroids or nerve blocks? Pain Clinic 1990; 3: 77-82.

72. Barnsley L, Lord SM, Wallis BJ, Bogduk N. Lack of effect of intra-articular corticosteroids for chronic pain in the cervical zygapophyseal joints. N Engl J Med 1994; 330: 1047-1050.

73. Murtagh FR. Computed tomography and fluoroscopy guided anesthesia and steroid injection in facet syndrome. Spine 1988; 13:686-689.

74. Destouet JM, Gilula LA, Murphy WA, Monsees B.. Lumbar facet joint injection: Indication, technique, clinical correlation, and preliminary results. Radiology 1982; 145: 321-325.

75. Lynch MC, Taylor JF. Facet joint injection for low back pain. A clinical study. J Bone Joint Surg Br 1986; 68:138-141.

76. Lippitt $A B$. The facet joint and its role in spine pain. Management with facet joint injections. Spine 1984; 9:746-750.

77. Lau LS, Littlejohn GO, Miller MH. Clinical evaluation of intra-articular injections for lumbar facet joint pain. Med J Aust 1985; 143:563-565.

78. Manchikanti L, Pampati VS, Bakhit C, Rivera JJ, Beyer CD, Damron KS, Barnhill RC. Effectiveness of lumbar facet joint nerve blocks in chronic low back pain: A randomized clinical trial. Pain Physician 2001; 4:101-117.

79. Manchikanti KN, Pampati V, Damron KS, McManus CD. A double-blind, controlled evaluation of the value of Sarapin in neural blockade. Pain Physician 2004; 7:5962.

80. Manchikanti L, Manchikanti KN, Damron KS, Pampati V. Effectiveness of cervical medial branch blocks in chronic neck pain: A prospective outcome study. Pain Physician 2004; 7:195-201.

81. Manchikanti L, Singh V, Pampati V. Are diagnostic lumbar medial branch blocks valid? Results of 2-year follow up. Pain Physician 2003; 6:147-153.

82. Lord SM, Barnsley L, Wallis BJ, McDonald GJ, Bogduk N. Percutaneous radiofrequency neurotomy for chronic cervical zygapophyseal joint pain. $N$ Eng J Med 1996; 335:1721-1726.

83. van Kleef M, Barendse GAM, Kessels A, Voets HM, Weber WE, de Lange S. Randomized trial of radiofrequency lumbar facet denervation for chronic low back pain. Spine 1999; 24:1937-1942.

84. Gallagher J, Vadi PLP, Wesley JR. Radiofrequency facet joint denervation in the treatment of low back pain - A prospective controlled double-blind study to assess efficacy. Pain Clinic 1994; 7:193-198. 
85. LeClaire R, Fortin L, Lambert R, Bergeron YM, Rossignol M. Radiofrequency facet joint denervation in the treatment of low back pain: a placebo-controlled clinical trial to assess efficacy. Spine 2001; 26:14111417.

86. Sanders M, Zuurmond WWA. Percutaneous intraarticular lumbar facet joint dener vation in the treatment of low back pain: A comparison with percutaneous extra-articular lumbar facet denervation. Pain Clin 1999; 11:329-335.

87. van Kleef M, Liem L, Lousberg R, Barendse G, Kessels F, Sluijter M. Radiofrequency lesion adjacent to the dorsal root ganglion for cervicobrachial pain. A prospective double blind randomized study. Neurosurgery 1996; 38:1127-1131.

88. Slappendel R, Crul BJ, Braak GJ, Geurts JW, Booij LH, Voerman VF, de Boo T. The efficacy of radiofrequency lesioning of the cervical spinal dorsal root ganglion in a double blinded randomized study: No difference between $40^{\circ} \mathrm{C}$ and $67^{\circ} \mathrm{C}$ treatments. Pain 1997; 73:159-163.

89. Sapir D, Gorup JM. Radiofrequency medial branch neurotomy in litigant and non-litigant patients with cervical whiplash. Spine 2001; 26:E268-E273.

90. Dreyfuss P, Halbrook B, Pauza K, Joshi A, McLarty J, Bogduk N. Efficacy and validity of radiofrequency neurotomy for chronic lumbar zygapophysial joint pain. Spine 2000; 25:1270-1277.

91. Schofferman J, Kine G. Effectiveness of repeated radiofrequency neurotomy for lumbar facet pain. Spine 2004; 29:2471-2473.

92. Stolker RJ, Vervest AC, Groen GJ. Percutaneous facet denervation in chronic thoracic spinal pain. Acta Neurochir 1993; 122: 82-90.

93. McDonald GJ, Lord SM, Bogduk N. Longterm follow-up of patients treated with cervical radiofrequency neurotomy for chronic neck pain. Neurosurgery 1999; 45: 61-68.

94. Tzaan WC, Tasker RR. Percutaneous radiofrequency facet rhizotomy - experience with 118 procedures and reappraisal of its value. Can J Neurol Sci 2000; 27:125-130.
95. North RB, Han M, Zahurak M, Kidd DH. Radiofrequency lumbar facet denervation: Analysis of prognostic factors. Pain 1994; 57:77-83.

96. Schaerer JP. Radiofrequency facet rhizotomy in the treatment of chronic neck and low back pain. Int Surg 1978; 63:53-59.

97. Vad VB, Cano WG, Basrai D et al. Role of radiofrequency denervation in lumbar zygapophyseal joint synovitis in baseball pitchers: a clinical experience. Pain Physician. 2003;6:307-312.

98. Muffolerro AJ, Nader R, Westmark RM, Nauta HJ, Garges KJ, Hadjipavlou AG. Hematogenous pyogenic facet joint infection of the subaxial cervical spine. A report of two cases and review of the literature. Neurosurg Spine 2001; 95:135-138.

99. Doita M, Nishida K, Miyamoto H, Yoshiya S, Kurosaka M, Nabeshima Y. Septic arthritis of bilateral lumbar facet joints: report of a case with MRI findings in the early stage. Spine 2003; 28:E198-202.

100. Orpen NM, Birch NC. Delayed presentation of septic arthritis of a lumbar facet joint after diagnostic facet joint injection. J Spinal Disord Tech 2003; 16:285-287.

101. Alcock E, Regaard A, Browne J. Facet joint injection: A rare form cause of epidural abscess formation. Pain 2003; 103:209210.

102. Magee M, Kannangara S, Dennien B, Lonergan R, Emmett L, van der Wall H. Paraspinal abscess complicating facet joint injection. Clin Nucl Med 2000; 25:71-73.

103. Windsor RE, Pinzon EG, Gore HC. Complications of common selective spinal injections: Prevention and management. $\mathrm{Am} \mathrm{J}$ Orthop 2000; 29:759-770.

104. Marks R, Semple AJ: Spinal anaesthesia after facet joint injection. Anaesthesia 1988; 43:65-66.

105. Cook NJ, Hanrahan P, Song S. Paraspinal abscess following facet joint injection. Clin Rheumatol 1999; 18:52-53.

106. Manchikanti L, Cash K, Moss T, Rivera JJ, Pampati V. Risk of whole body radiation exposure and protective measures in fluoroscopically guided interventional techniques: A prospective evaluation. $B M C$
Anesthesiol 2003; 3:2.

107. Berrigan T. Chemical meningism after lumbar facet joint block. Anesthesia 1992 7:905-906.

108. Thomson SJ, Lomax DM, Collett BJ. Chemical meningism after lumbar facet joint nerve block with local anesthetic and steroids. Anesthesia 1993; 46:563-564.

109. Raj PP, Shah RV, Kay AD, Denaro S, Hoover $J M$. Bleeding risk in interventional pain practice: Assessment, management, and review of the literature. Pain Physician 2004; 7:3-52.

110. Dreyfuss P, Kaplan M, Dreyer SJ. Zygapophyseal joint injection techniques in the spinal axis. In Lennard T (ed.) Pain Procedures in Clinical Practice, $2^{\text {nd }}$ ed. Hanley \& Belfus, Inc., Philadelphia, 2000, pp 276-308.

111. Manchikanti L. Role of neuraxial steroids in interventional pain management. Pain Physician 2002; 5:182-199.

112. Manchikanti L, Pampati V, Beyer C, Damron KS, Cash KA, Moss TL. The effect of neuraxial steroids on weight and bone mass density: A prospective evaluation. Pain Physician 2000; 3:357-366.

113. Kornick CA, Kramarich SS, Lamer TJ, Sitzman BT. Complications of lumbar facet radiofrequency denervation. Spine 2004; 29:1352-1354.

114. Windsor RE, Storm S, Sugar R. Prevention and management of complications resulting from common spinal injections. Pain Physician 2003; 6:473-484.

115. Slavin RE. Best-evidence synthesis: An alternative to meta-analytical and traditional reviews. Educational Researcher 1986; 9:5-11.

116. Hopayian K. The need for caution in interpreting high quality systematic reviews. BMJ 2001; 323:681-684.

117. Manchikanti L. Evidence-based interventional pain medicine: Is there any evidence? Pain Physician 2002; 5:1-7.

118. Bogduk N. In defense of radiofrequency neurotomy. Letter to the editor. Reg Anesth Pain Med 2002; 27:439-447. 